\title{
Treatment and Disposal Technology of Surplus Sludge in Urban and Town Sewage Treatment Plant
}

\author{
LiJia \\ College of Architecture and Civil Engineering of Beijing University of Technology,Beijing, China
}

\begin{abstract}
: with the continuous acceleration of urban and town construction, the output of urban and town sewage is also increasing. To a great extent, this promotes the technological development and capacity expansion of urban and town sewage treatment plants. In the process of sewage treatment, a lot of sludge is inevitable. However, many urban and town sewage treatment plants pay more attention to the treatment of sewage and ignore the treatment of sludge. In this way, the sludge without proper treatment can be disposed at will. In the long run, this will not only affect the surrounding environment, but also hinder the development of social economy. Therefore, the urban and town sewage treatment plant should pay enough attention to the application of surplus sludge treatment and disposal technology. In this paper, the main problems existing in the treatment and disposal technology of surplus sludge in urban and town sewage treatment plants, and the treatment and disposal technology of surplus sludge in urban and town sewage treatment plants are both explored and analyzed, hoping to contribute to the long-term development of urban and town sewage treatment plants.
\end{abstract}

In recent years, with the rapid development of urban and town sewage treatment plants, the treatment of sewage is more and more in-depth. However, some sludge will be produced at the same time of sewage treatment. Therefore, the sludge treatment is also an urgent problem to be solved in urban and town sewage treatment plants at this stage. In recent years, with the increasing attention paid by the state to the sludge problem, the development and introduction speed of sludge treatment and disposal technology has been accelerated obviously. This greatly improves the scientific sludge treatment, solves the problems of urban sewage and sludge, and thereby the urban environment is well protected.

\section{The main problems existing in the treatment and disposal technology of surplus sludge in urban and town sewage treatment plant at present}

According to the actual situation of urban and town sewage treatment plants in China at present, the methods of sludge treatment and disposal mainly include agricultural utilization, drying treatment and direct landfill. From the relevant investigation, the direct landfill method is often adopted in the treatment and disposal of sludge for urban and town sewage treatment plants. Although the sludge treatment method is relatively simple to operate, it is also easy to cause a series of problems. Firstly, in the process of landfill sludge, it will cause waste of land resources, and there are not enough sites for landfill sludge in cities and towns. Secondly, in case of rainy days, the sludge is likely to cause certain harm to the landfill soil under the influence of rainwater. If the landfill is not good, it is likely to pollute the groundwater. Thirdly, in the process of using landfill method to treat the sludge, a kind of gas with little or no occurrence on landfill sites is usually produced. And the emergence of this gas is likely to lead to environmental air pollution, which will cause environmental security risks.

As we all know, China is a large agricultural country. The best way for urban and town sewage treatment plant to treat and dispose the sludge is to expand the land use rate and meanwhile effectively treat the sludge. The surplus sludge of urban and town sewage treatment plant usually contains more $\mathrm{P}, \mathrm{N}$ and other elements, which are good agricultural fertilizer. However, in the process of sludge treatment and disposal in many urban and town sewage treatment plants, there is no proper treatment and reasonable utilization, resulting in a large number of sludge into new environmental pollutants.

\section{Surplus sludge treatment technology for urban and town sewage treatment plants}

Sludge treatment technology refers to the harmless process of stabilizing and reducing sludge. Sludge treatment technology mainly includes anaerobic digestion technology and aerobic fermentation technology.

\section{(1) Sludge anaerobic digestion technology}

The surplus sludge of urban and town sewage treatment plant usually contains rich organic matter. The 
application of sludge anaerobic digestion technology needs to make full use of anaerobic microorganisms to decompose the organic matter in sludge and decompose it into a stable substance under anaerobic conditions. In this process, there will also be the combustible gas based on the methane.

The application of sludge anaerobic digestion technology can significantly reduce the sludge volume, and also decrease the organic matter in sludge. Thus, it can improve the dewatering performance of the sludge, produce biogas, and greatly improve the utilization of resources. At present, both at home and abroad, anaerobic digestion technology of the sludge has developed more mature, more successful cases. However, in the initial stage of using sludge anaerobic digestion technology to recover energy, a lot of money is usually needed. Only in this way can a certain scale effect be produced, and the requirement of organic content in sludge is relatively high. However, at present, the diversion of rainwater and sludge in most cities of China is not thorough enough, and the sewage contains more sediment. This results in a low probability of gas generation in the process of applying sludge anaerobic digestion technology. This will greatly increase the cost of operation and maintenance of urban and town sewage treatment plant, and also hinder the promotion of sludge anaerobic digestion technology.

\section{(2) Sludge aerobic fermentation technology}

Sludge aerobic fermentation technology is to pile up sludge under aerobic conditions, so that the organic matter in sludge can be fermented under the action of microorganisms. In this way, the relatively stable humus can be formed. In the process of aerobic fermentation, a certain amount of heat will be released, forming a high temperature environment higher than $55^{\circ} \mathrm{C}$. In this environment, pathogenic microorganisms will be killed, so as to achieve the purpose of sludge harmlessness and reduction. After the sludge is formed into compost products by aerobic fermentation, its volume and weight will be reduced, and its texture is relatively soft. After fermentation, the nutrients beneficial to plant growth will be significantly increased, and the pathogenic bacteria and parasite eggs will be basically eliminated ${ }^{[1]}$. At the same time, after fermentation, the sludge is more convenient for storage and transportation, and is a very good fertilizer and soil improver.

After aerobic fermentation, the water content of sludge will be reduced to less than $35 \%$. The volume of sludge will be obviously smaller, and the odor of sludge itself will disappear. At the same time, the properties of sludge will be improved, and the utilization rate of sludge resources will be improved. In the process of using sludge aerobic fermentation technology, the initial investment is relatively small, and the application of this technology can greatly improve the land utilization. At present, many cities in our country have built sludge aerobic fermentation projects.

\section{Disposal technology of surplus sludge}

\section{in urban and town sewage treatment plant}

Sludge disposal technology is to ensure that the human health and ecological environment will not be damaged by means of the final sludge absorption technology. It mainly includes the utilization of building materials, sludge incineration, sanitary landfill and land utilization.

\section{(1) Utilization of building materials}

Sludge utilization and disposal technology of building materials refers to the direct use of sludge as raw materials for building-materials manufacturing. Then the final product of sludge after sintering can be directly made into construction materials. Building materials and products mainly include: additive for manufacturing bricks and cement, etc.

In the process of cement production, the sludge can be put in cement kiln for high temperature incineration. After a series of physical and chemical reactions, the product of sludge incineration is solidified in the lattice of cement clinker. Thus it becomes a component of cement, and then achieves the purpose of safe disposal for the sludge. From the actual situation at home and abroad, the sludge has accumulated a lot of successful experience in the application of cement burning, and in many areas of our country, there are cement clinker burning projects. The use of sludge in cement burning is still a kind of sludge incineration. It should be noted that the proportion of sludge mixed with burning should not exceed $20 \%$. However, the cost of this sludge disposal method is relatively high. The sludge disposal method is suitable for areas without land use requirements and where cement kilns have been built.

\section{(2) Sludge incineration}

Sludge incineration disposal technology refers to the incineration of sludge in special or non-special incinerators, and makes full use of the generated heat. In addition, some flying ash is usually generated after the incineration of sludge. When using this technology, the flying ash should also be disposed innocuously ${ }^{[2]}$. The incineration of sludge can achieve the purpose of sludge reduction to the maximum extent, kill the pathogenic bacteria and microorganisms, and oxidize the toxic pollutants.

The water content of sludge is usually higher, and the heat value of sludge itself is lower. Therefore, it is difficult to maintain combustion with its own heat. If the sludge can burn continuously, it needs to add some auxiliary fuel properly. In practical application of sludge incineration technology, municipal sewage treatment plants usually burn sludge together with local garbage. Or the sludge is put in kilns of cement burning, thermal power generation and other industries to burn together. This is because the special sludge incineration needs high cost, and it is easy to produce some pollutants. Also, this will lead to the destruction of some nutrients originally contained in the sludge that are beneficial to 
plant growth. Moreover, if there is a large amount of sand in the sludge, it will cause serious wear to the boiler in the process of incineration.

\section{(3) Sanitary landfill}

The application of sanitary-landfill disposal technology needs to standardize the process of sludge sanitary landfill based on $<$ the technical specification for sanitary landfill of daily waste $>$.

According to the actual development of the disposal technology of sanitary landfill sludge, there are still some problems: the water content of sludge is higher, and the total amount of sludge is too large ${ }^{[3]}$. Therefore, in the process of sludge landfill, the landfill body is prone to landslide and deformation. In addition, it may also cause certain impact on the environment and occupy a large number of storage capacities of landfill factories. This will seriously affect the service life of the landfill factories, making the effective land resources of the landfill factories much less.

Although there are still some problems in the disposal technology of sanitary landfill sludge, it is still a kind of sludge disposal method often used by municipal sewage treatment plants at present. In the process of sanitary landfill sludge, the odor and exudate produced at the same time will cause certain pollution to the environment. From a certain point of view, the application of sanitary landfill-sludge disposal technology can not completely avoid the risk of environmental pollution. It can only delay environmental pollution. Therefore, the municipal sewage treatment plant can't use this sludge treatment method for a long time.

\section{(4) Land utilization}

There are not only a lot of organic matters in the sludge, but also rich in nitrogen, phosphorus, potassium and other elements, which are conducive to the growth of living beings. Therefore, applying appropriate amount of sludge to the soil can improve the properties of the soil from chemical, physical and biological aspects. Sludge land utilization and disposal technology is to use the sludge which has been treated stably and innocuously as organic fertilizer and nutrient soil in forestry, agriculture and soil improvement. In this way, the utilization rate of sludge can be improved, the value of organics and nutrients in sludge can be brought into full play, and the sludge can be disposed reasonably at the same time.

Sludge land utilization and disposal technology is a technology often used in the disposal of sludge in European and American countries, and it is also a sludge disposal technology advocated by European and American countries ${ }^{[4]}$. However, in China there are still some problems to be solved in the application of sludge land utilization and disposal technology currently. In China, the proportion of industrial wastewater in urban and town sewage is very large. This also leads to the high content of heavy metals in the surplus sludge from sewage treatment plants in many urban and town areas. If not handled properly, it is likely to pollute the land, and this will also affect the utilization of land-use sludge disposal technology to a certain extent.

\section{The developmental trend of surplus sludge treatment and disposal technology in urban and town sewage treatment plant}

In recent years, the problem of environmental pollution in China has become more and more serious. The main purpose of operation and development of urban and town sewage treatment plant is not only sewage treatment, but also the treatment and disposal of surplus sludge ${ }^{[5]}$. The application of surplus sludge treatment and disposal technology in urban and town sewage treatment plant can not only achieve the effect of sludge stabilization, harmlessness and reduction, but also improve the utilization rate of sludge resources. Faced with the increasingly polluted environment, urban and town sewage treatment plants should establish the concept of energy conservation, environmental protection and safety. At the same time, we should adhere to the basic principles of energy conservation and emission reduction. Through continuous exploration and analysis, we can continuously improve the technical level of surplus sludge treatment and disposal in urban and town sewage treatment plant.

\section{Conclusion}

To sum up, with the prominent problem of surplus sludge in urban and town sewage treatment plants, relevant policies and regulations have been continuously issued at the national level, and relevant special projects and other major studies have been continuously promoted and deepened. The speed, quality and quantity of research and introduction of sludge treatment and disposal technology in China have been significantly improved. Therefore, in the near future, both urban sewage treatment plants and centralized sludge treatment and disposal plants will pay more attention to and strengthen the application of surplus sludge treatment and disposal technology. At the same time, there will be the industry situation like a variety of process technologies and treatment scale emerges. All of these will help us to improve the utilization rate of resources while protecting the environment.

\section{References}

1. Wang Jing. Influence of odor from sludge treatment in sewage treatment plant on surrounding air environment $[\mathrm{J}]$. Environment and Development, 2019,31 (10): 48+50.

2. Wang Hongchen. Pay attention to the operation dilemma of urban sewage treatment plant, and jointly explore solutions [J]. Water Supply and Drainage, 2019,55 (09): 1-3. 
3. Li Jiaqi. Discussion on the upgrading of urban sewage treatment plant[J]. Energy Saving, 2019,38 (08): 141-142.

4. Hu Yuefen, Huang Canke. Synthesis and acid resistance test of one component geo-polymer of fly ash and sludge of urban sewage treatment plant [J]. Chemical Engineer, 2019,33 (07): 39-42.

5. Qu Kaicheng. Study on sludge treatment stability standard of urban sewage treatment plant [J]. Agricultural Advices, 2019 (13): 174. 